\title{
Adolescentes, Seus Professores: Enredos da Dinâmica Intersubjetiva em Sala de Aula
}

\author{
Cristiani Debacker; Vânia Monteiro de Menezes \& Vera Lúcia Blum* \\ Universidade Federal de Mato Grosso, Cuiabá, Brasil
}

\begin{abstract}
RESUMO
Este artigo procura evidenciar aspectos da dinâmica intersubjetiva em sala de aula a partir de recortes no discurso de oito adolescentes sobre suas vivências em uma escola pública. A escuta revela como o desabrochar da vida sexual pode enredar o professor em situações que põem em risco sua autoridade docente. Significativo também é como o efeito de destaque produzido pelo elogio em sala de aula revela neste uma face inconveniente. A análise, psicanaliticamente orientada das elocuções do grupo, indica como as respostas do professor ao modo como é visto por seus alunos podem favorecer ou dificultar a dinâmica intersubjetiva. Conclui-se que o desejo de aprender dos alunos depende, em parte, do reconhecimento das singularidades adolescentes implicado nessas respostas.
\end{abstract}

Palavras-chave: adolescentes; sexualidade; singularidade; elogio.

\begin{abstract}
Teenagers, Their Teachers: Plots of the Intersubjective Dynamics in Classroom

Based on the outcomes of a focus group in which eight teenagers discussed about their experience in a public school this article seeks to underscore aspects of the intersubjective dynamics in the classroom. The speeches of the teenagers reveal how the unfolding of their sexual life can lead teachers to become entangled in situations that put their authority at stake. It is also meaningful that the highlight effect produced by compliments to the students in the classroom reveals an inconvenient side effect. A psychoanalytically oriented analysis of the utterances of the group indicates how the responses of the teacher to the way he or she is perceived by the students can promote or prevent the intersubjective dynamic. From this it is concluded that the student's desire to learn depends partially in the acknowledgment of the singularities of the teenagers.

Keywords: teenagers; sexuality; singularity; compliments.
\end{abstract}

A adolescência, um período que se estende dos 12 aos 21 anos, aproximadamente, é uma construção social que, de acordo com Ariès (2006), surge com o adensamento do sentimento das idades e da infância a ocorrer em paralelo com a evolução da instituição escolar e se consolida no século XIX.

Se na adolescência, de natural e universal, o que há são mudanças corporais, o modo como se vivencia a perda do corpo infantil está ligado às condições sociais de determinada época. Do ponto de vista psicológico e culturalmente circunscrito, o luto pelo corpo infantil é acompanhado por vivências de natureza conflitiva, de crises, incertezas e desequilíbrios. Em lugar da segurança que lhe era oferecida durante a infância, o adolescente espera receber do adulto um olhar que o reconheça como outro adulto, porém isso não acontece (Calligaris, 2000). Como resposta a essa recusa o adolescente procura adotar comportamentos capazes de distingui-lo tanto dos adultos como das crianças. As ambiguidades com as quais os jovens têm que lidar e que assinalam as hesitações entre os anseios de autonomia e o desejo infantil de dependência da autoridade parental são fonte de confusão e desconforto. Isto os obriga a buscar meios de se destacar pela recusa dos índices de sua dependência: os valores compartilhados pelas figuras parentais. Tal recusa é concomitante à formação do grupo que, ao dar sustentação às inquietações de cada um entre vários e por meio das identificações que aí se produzem, favorece a formação de uma nova identidade. Para Knobel (1992), a procura por uniformidade, que proporciona segurança e estima pessoal é a origem do espírito de

\footnotetext{
Endereço para correspondência: Vera Lúcia Blum - verablum@terra.com.br
} 
grupo, em um processo de superidentificação, que possibilita a todos a identificação entre si. Conforme a fala dos adolescentes, é no grupo que eles se sentem à vontade para expressar suas ideias, sentimentos e desejos, dividir gostos por músicas, roupas, looks, esportes etc. É na expressão de suas ideias no interior do grupo que eles podem se firmar como indivíduos singulares, embora para o olhar externo pareça haver indiferenciação entre seus membros.

Para pertencer a um determinado grupo o indivíduo deve se submeter a algumas provas, que lhe servem de passaporte para passar de um status social a outro. Para marcar a entrada do jovem na condição de adulto, encontramos, nas mais variadas sociedades, rituais de iniciação culturalmente determinados. A título de ilustração, no mundo ocidental, entre os ritos oferecidos pelos adultos, o baile de debutante, ritual vindo da Europa, serve para que os pais apresentem à sociedade a menina que deixa a condição de criança. A Igreja Católica oferece o sacramento da Crisma ritual em que o indivíduo é responsável pela confirmação do ato realizado por seus pais e padrinhos no batismo. Na sociedade judaica, os Bar e Bat Mitzvah são cerimônias nas quais se comemora a iniciação dos meninos e das meninas à vida adulta. De acordo com Figueiredo (2009), os rituais são dispositivos de recepção do sujeito a uma nova condição social e, ao reposicioná-lo entre seus pares e semelhantes, representam pontos de passagem de uma condição subjetiva a outra.

Além da oportunidade de pertencer a um grupo, os adolescentes buscam também ídolos, pessoas em quem se espelhar e desse modo construir sua imagem identitária. No mundo pós-moderno, todavia, encontrar um padrão ideal a servir como modelo não é tarefa fácil, uma vez que as referências disponíveis para as identificações em um mundo globalizado como o nosso "se contrapõem, são múltiplas, invalidam-se" (Forbes, 2005, p. 5).

A formação da personalidade não segue um modelo único, vai sendo construída a partir de recortes das individualidades existentes e que interessam a cada um de forma singular. Outeiral (1994) nos lembra da importância da escola como espaço e processo de socialização e seu papel na construção da identidade do adolescente. A função da escola não se limita à transmissão do saber curricular. Ao reproduzir o sistema social, ela funciona como uma microssociedade que exerce um conjunto de forças sobre o adolescente na busca de sua identidade. $\mathrm{O}$ autor ressalta que qualquer escola tem uma cultura própria, à qual determi- nado aluno pode ou não se adaptar, em virtude das transferências que estabelece com ela.

A escola apresenta uma influência significativa na vida do adolescente, posto que os adultos que a representam, em particular os professores, lhe servem como modelos de identificação ou contraidentificação na construção de seu devir adulto. Na busca de modelos com os quais venha a se identificar, o adolescente torna-se um aplicado perscrutador do comportamento adulto, de modo que, é de se supor, o olhar acurado do adolescente é um forte aliado para a melhoria das relações éticas e afetivas em sala de aula.

Escutar os jovens é tarefa desejável, todavia problemática. Desejável porque a sensibilidade ética do educador depende de que ele se coloque na posição de quem se dirige a um interlocutor. Problemática porque o dizer do aluno perturba a consciência que o professor tem de si e de suas certezas e isto leva a um confronto direto com suas próprias dificuldades, o que nem sempre é fácil de suportar.

Com base na hipótese de que em sala de aula estão presentes elementos geradores do antiprocessual na aprendizagem -, as projeções e identificações cruzadas entre alunos e professores - que fazem parte da construção de uma trama imaginária na qual ficam amarrados professores e alunos (Blum, 2008), o objetivo deste artigo é identificar modos adolescentes de sentir, pensar e agir propícios a enredar o professor em situações que põem em risco sua autoridade docente. Com esse intuito, reunimos um grupo de adolescentes interessados em discutir e comentar sobre suas vivências. A polifonia das vozes é organizada, neste artigo, segundo dois planos de escuta que sinalizam alguns impasses nas relações entre alunos e professores em sala de aula: a pressão que a sexualidade adolescente exerce sobre o professor e o modo como os adolescentes reagem ao elogio em sala de aula. Esses dois planos convergem nas associações com a literatura psicanalítica pelas quais nos deixamos levar, as quais repercutem, no plano conceitual, as ambivalências adolescentes perante a figura de autoridade que o professor representa.

Espera-se que este artigo possa contribuir com a elucidação de algumas forças em jogo na dinâmica intersubjetiva em sala de aula, as quais podem expor a risco o processo de aprendizagem. 


\section{MÉTODO}

Para a realização deste trabalho nos inspiramos na técnica do grupo focal, que "oferece boa oportunidade para a geração de teorizações exploratórias até mais do que para a verificação ou teste de hipóteses prévias" (Gatti, 2005, p. 13, itálico nosso). A técnica é um instrumento da pesquisa qualitativa que reúne em um determinado espaço e por algum tempo um conjunto de pessoas, cuja tarefa é discutir e comentar um tema, que é objeto de pesquisa, tendo como referência sua experiência pessoal.

\section{Participantes}

Em busca de uma oportunidade para mapearmos situações de desconforto que marcam as experiências nas lides corriqueiras em sala de aula, decidimos reunir um grupo de adolescentes para falarem sobre suas relações entre si e com seus professores. Optamos por uma escola da rede pública de Cuiabá (MT) que tem por característica a disponibilidade para se envolver em parcerias com projetos acadêmicos universitários.

Trata-se de uma escola estadual do Ensino Fundamental situada em bairro de classe média baixa, cuja clientela é moradora do bairro e arredores. Na primeira visita agendada, apresentamos à diretora o objetivo da pesquisa, o método que seria utilizado e o cronograma. Diante do seu consentimento, passamos de sala em sala nas três turmas do nono ano para convidar os alunos a participarem da atividade. Explicamos que, para os interessados, seria imprescindível a entrega da autorização assinada pelos pais no primeiro dia de reunião e para tanto deixaríamos na diretoria cópias da carta de autorização.

Obtido o consentimento da direção para o projeto e instruídos os alunos, compusemos o grupo de discussão com base nas instruções de Gatti (2005). De acordo com ela, para o trabalho em um grupo focal é necessário que haja, no mínimo, quatro integrantes, a fim de que sejam garantidos o dinamismo e a diversidade de opinião e, no máximo, doze, para possibilitar que todos expressem suas ideias. Desse modo, entre os dez adolescentes interessados em participar do projeto, optamos por oito sujeitos escolhidos aleatoriamente, por ser esse o número médio do intervalo proposto por Gatti. O grupo foi então composto por seis meninas e dois meninos, com idade entre 13 e 15 anos, estudantes da $3^{\text {a }}$ Fase do III Ciclo do Ensino Fundamental, referida normalmente como nono ano.

\section{Procedimento}

Antes da realização dos encontros elaboramos um roteiro de debate, com questões referentes aos tópicos centrais de discussão: o que é ser adolescente, como ele lida com a condição de não ser mais criança e ainda não ser adulto, como é a relação do adolescente com outros adolescentes, se existe ou não a formação de "grupinhos" e disputa entre eles na escola e, em caso afirmativo, por que isso acontece, como o grupo os influencia, como é a relação dos adolescentes com os professores e se a relação professor-aluno influencia na aprendizagem.

Formado o grupo, procedemos à explicitação do enquadre, que constitui uma espécie de contrato oral, no qual são explicitadas, delimitadas e acordadas as normas que regulam o trabalho a ser desenvolvido. Ficou determinado que teríamos quatro encontros cujo tema seriam as relações estabelecidas no ambiente escolar. Definiu-se que esses encontros ocorreriam após o término das aulas do dia, das 11 às 12 horas, na biblioteca da escola. Enfatizamos a importância da participação de todos, nos dias e hora marcados, bem como ressaltamos nosso compromisso com o sigilo: nada do que fosse dito nas reuniões seria levado ao conhecimento da coordenação ou do corpo docente da escola.

O trabalho envolveu a participação de um observador e de um mediador. O mediador desempenhou a função central de abrir, estimular o desenvolvimento e concluir os debates. Ele teve o papel de manter o foco da discussão e encorajar os participantes a se expressarem. Ao observador coube a função de captar as informações não verbais expressas pelos participantes e exercer o papel de interlocutor na análise dos dados. Todos os encontros foram registrados por meio de gravações e posteriormente transcritos. A fim de proteger a identidade de cada um dos participantes, os nomes foram substituídos, neste trabalho, pelas letras $\mathrm{F}$ para as meninas e $\mathrm{M}$ para os meninos.

\section{ANÁLISE DOS DADOS}

O material discursivo proveniente das discussões foi submetido à análise, que levou em consideração o fato de que as opiniões expressadas estão ancoradas nas experiências cotidianas, as quais, por sua vez, estão ligadas ao universo subjetivo dos adolescentes. É essa ligação que nos permite escutar as falas como respostas ao modo como percebem as situações e não como relatos ou descrições das situações em si. 
A análise dos dados se faz pelo recorte das elocuções produzidas no grupo, contudo, não aleatoriamente. É um recorte que procura evidenciar algo do universo subjetivo dos adolescentes que vai além do conteúdo manifesto e que pode estar operando de forma benigna ou não na dinâmica intersubjetiva em sala de aula, de modo a favorecer ou não os processos cognitivos implicados nas tarefas de ensinar e aprender.

Utilizamos como procedimento para a análise dos dados a escuta das vozes que insinuam um sentido possível de ser formado com o auxílio de ferramentas conceituais. As elocuções sugestivas direcionam a escolha das noções psicanalíticas, que são convocadas para ajudar a dar forma a um ou outro fragmento do discurso significativo das relações que os jovens estabelecem com seus pares e com os adultos. Os resultados e a discussão do material coletado são, por conseguinte, efeito de interpretações ou construções de sentidos que estão na fala dos adolescentes e naquilo que a escuta cria a partir dessas falas.

\section{RESULTADOS E DISCUSSÃO}

As falas a seguir dão uma pequena amostra do caleidoscópio que é o constructo adolescência quando enunciado do ponto de vista do sujeito que a vive. Procuramos organizar a polifonia das vozes segundo dois planos de escuta: a sexualidade adolescente e os efeitos subjetivos, no grupo de adolescentes, perante o elogio do professor ao desempenho de um aluno.

\section{O desabrochar da vida sexual e seus enredos}

Quando indagados sobre o que é ser adolescente, os jovens declaram que essa fase é marcada pela incompreensão e desconfiança quanto à veracidade do que é dito. Para eles, às vezes é necessário mentir porque, se disserem a verdade, serão punidos. O sentimento de não serem compreendidos ou dignos de confiança acaba por afastá-los dos adultos. É o velho conflito de gerações que se parece com uma cobra que morde a própria cauda - a falta de compreensão ou confiança faz com que os jovens se esquivem e a esquiva só aumenta a incomunicabilidade e a falta de compreensão mútua.

Eles sabem, entretanto, que a lente pela qual fitam o mundo é uma lente de aumento, que tem na insubmissão seu escopo. Os adolescentes reconhecem sua rebeldia ("adolescência é rebeldia na certa!"), e sabem dos conflitos que emergem ao passarem pelas transições típicas dessa fase. $\mathrm{Na}$ fala dos jovens o período é caracterizado por transformações e confu- sões. Em que se orientar se nem o suporte material da imagem de si corresponde à imagem construída daquele corpo ao longo dos anos da infância?

Quando questionados sobre como se consideravam, criança ou adulto, a resposta foi unânime e dita em coro: "Adolescentes!". Ao escapar das categorias propostas, ela revela que o conceito de "adolescente" - socialmente construído - está a serviço de uma constituição subjetiva protetora da ambivalência. Essa construção social é subjetivada como uma positividade que protege da angústia do não-lugar: já não mais criança e ainda não adulto. Adolescente.

O que antes interessava, atraía a atenção, perde importância, de modo natural ou como forma de protesto. Uma das formas de lidar com a confusão que a transformação corporal acarreta é passar a discriminar e a ordenar comportamentos próprios à nova condição. Entre as coisas da infância que são abandonadas, há as que simplesmente perdem seu interesse e há as que devem perder, porque "não pegam bem" para um adolescente. O trânsito da condição subjetiva de criança para adolescente se dá por meio da produção de distinções, de diferenças e hierarquizações e é visível quando os participantes da pesquisa, todos do nono ano ${ }^{1}$, classificam como impróprios os comportamentos dos alunos do sexto ano para deles tomar distância:

$E$, porque as turmas da $8^{a}$ série não se misturam com as da $5^{a}$ série. Os alunos da $5^{a}$ série são aquelas crianças que estão chegando agora da $4^{a}$ série, ainda querem brincar, não entendem que há regras na escola. Elas querem brincar, querem correr no recreio. Já a $8^{a}$ série é mais fechada e a gente não vai sentar e conversar com eles porque a gente é superior. (F1)

Cumpre, no entanto, indagar o quanto esse sentir-se superior em relação aos alunos mais novos não vem mascarar um ressentimento em relação a eles. Afinal, os alunos da $5^{\text {a }}$ série nem tomam conhecimento de que a escola tem regras e só querem saber de correr, brincar, gozar. Na fala dos adolescentes é perceptível o sentimento de que recebem menos carinho, amor, atenção e delicadeza do que as crianças. É possível que isso não corresponda à realidade, pelo menos não em todas as ocasiões, porém é desse modo que o adolescente a vê e sente. Um das jovens relata que em sua turma o professor entra na sala e manda calar a boca, ao passo que um trato mais delicado é reservado apenas às crianças.

$\mathrm{O}$ adolescente se sente apto a ter os mesmos comportamentos dos adultos, porém é barrado. E, ao 
mesmo tempo, deixa de ser considerado e protegido como uma criança. Segundo Calligaris (2000) o adolescente perde a proteção que recebia na infância ou a ela renuncia e espera que essa renúncia lhe traga o reconhecimento, pelo adulto, de que agora ele também é adulto, seu par iminente, mas isso não se realiza. É duro perder e é duro não ganhar. $\mathrm{O}$ adolescente acaba por sentir-se pelas duas vias frustrado. Ele não ganha a liberdade que deseja e também perde o olhar do adulto, que o protegia quando suas feições eram mais arredondadas e despertavam nos pais e nos professores um afeto aparentemente incondicional.

Esse sentimento de perda de afeto pode ser vivenciado na família quando o amor dos pais tem que ser dividido com os irmãos, principalmente se esses forem mais novos. Para F3 a mãe dá mais carinho para os meio-irmãos do que para ela, com a justificativa de que eles são menores, argumento que não a convence. Além disso, F3 se queixa de que a mãe não conversa com ela e não a compreende.

Ao mesmo tempo que o adolescente entra em contato com os efeitos do enfraquecimento da fantasia de ser o objeto exclusivo da afeição inabalável dos pais, aparecem fantasias de perigo relacionado ao desejo sexual, que se fazem atuar na realidade. Os adolescentes do grupo alinhavam ao seu desprezo pelos menores o incremento da sexualidade, da qual, tentadora e assustadora, desejam usufruir, ao mesmo tempo que a temem. F4 afirma que os pais, em geral, não aceitam que a menina tenha relações amorosas. Para eles, suas filhas devem se dedicar apenas aos estudos e deixar as relações amorosas para quando tiverem mais maturidade.

O temor perante o desabrochar da vida sexual é um afeto que, aparentemente, não é vivido pelas adolescentes. No entanto, ao trazerem à tona o tema da contenção e limitação da vida sexual exercida pelos pais, elas revelam, a partir do registro externo (ideia de perigo e proteção parental por meio da proibição), o que está ocorrendo no registro interno: o lançamento para fora de si da percepção endopsíquica dos ataques que a pulsão sexual provoca e de um modo ou de outro precisa ser tramitada. É o que aparece no relato das adolescentes:

A minha mãe não gosta que eu vá na lan house, porque lá tem o perigo de ser assaltada. Ela tem muito medo. (F2)

Pro meu pai o computador é a morte, [pai] "vai ser estuprada, tem pedofilia”. [Eu falo] "Pai, só cai nessa quem é idiota ou deficiente ou quem não sabe usar o computador". Ainda mais agora que uma menina, lá perto de casa, marcou encontro com um cara pela internet e foi estuprada por três caras. (F5)

Produzir ligações com objetos culturais é uma das formas de fazer escoar a energia sexual. Nota-se certa incompreensão desse aspecto da vida pulsional, quando F1 narra a reação do pai a um anseio seu, trivial em nossa cultura e comum ao repertório da vida social de um jovem - o passeio ao Shopping Center:

\begin{abstract}
"Pai, quero ir ao shopping”. [O pai pergunta] "Ir ao shopping pra quê?? Você quer comer no shopping, eu vou lá compro uma pizza e a gente come em casa". "Pai, eu não vou pra comer nada, eu vou pra ver as coisas, ver as lojas, conhecer um pouco de gente”. [Pai] "Você já quer é namorar! Praga, não tem nem cabelo não sei naonde [sic] e já quer namorar!’. (F1)
\end{abstract}

A proibição dos pais é geralmente entendida como um medo justificado de que algo de ruim aconteça ao adolescente, visto como um ser que ainda não aprendeu a se defender dos perigos que o mundo oferece. No entanto, o que dizer das situações em que a autoridade parental ultrapassa alguns limites e mesmo assim é obedecida e respeitada? Nessas situações, os adolescentes parecem acreditar que o excesso de rigor é justificado pelo amor. Este, conjecturamos, é um amor idealizado, a serviço da negação da dor e da repressão da raiva. A esse respeito, as adolescentes relatam:

Depois que meu pai me viu com um menino na rua, ele me chamou pra conversar, e tirou o cinto. Eu gelei! [Pai] "Não, eu não vou te bater agora”. Ele me deu o maior sermão e perguntou se eu não tinha felicidade dentro de casa pra ir procurar na rua. Aí ele me disse: "Agora você sabe por que você vai apanhar" e me bateu. Mais tarde ele veio me pedir desculpa... Depois que eu levei aquela surra eu não quero mais ficar, eu quero namorar sério. (F2)

F1, na sequência, relata sua experiência: "meu pai já bateu umas duas vezes na minha cara e eu não tenho raiva dele por causa disso, porque pai sabe o que é melhor pra filha". Considerando que se vai apanhar de qualquer jeito, "é melhor você apanhar de seu pai hoje do que apanhar de outro homem amanhã", que a ação seja executada pelo pai: "eu acho mil vezes melhor o pai, que te ama, te bater".

Outro relato feito por F2 diz respeito a uma amiga, submetida a maus-tratos pela mãe. A menina era insultada com palavrões e agredida com surras de vas- 
soura ou qual fosse o objeto que lhe estivesse à mão. Ao ver marcas no corpo da amiga, F2 lhe questionou a razão de ela não abandonar a mãe, sair de casa, já que ela tinha tudo para ser "roqueira, revoltada", e teve a seguinte resposta: "Não, eu não sou revoltada porque eu tenho mentalidade, e eu não vou ligar para o que minha mãe fala porque eu sei que ela me ama. Só que ela tem um modo diferente de expressar esse amor".

Nesse ponto, o discurso dos adolescentes parece subitamente regredir. Da ânsia por emancipação e liberdade, repentinamente se introduz no discurso uma obediência cega, difícil de explicar. Nas situações narradas, a submissão aos castigos físicos, essa invasão feita ao corpo, é não só aceita como prontamente perdoada. A agressão leva à anuência a uma lição moral da qual ela é supostamente veículo. "Tomar vergonha na cara" aparece, no discurso das adolescentes, como a consequência lógica de ser surrada.

A sujeição à fúria parental mobilizada pela sexualidade adolescente põe em relevo uma demanda de amor traiçoeira. Nas entrelinhas, as jovens parecem dizer que submeter-se à vontade parental para garantir seu amor é mais importante do que saber da própria sexualidade, por ela se orientar ou a ela renunciar, enfim, realizar-se em seu próprio nome. Por outro lado, é possível que isto que aparece como submissão seja a resultante da identificação, mecanismo pelo qual se dá a transmissão psíquica, inclusive dos valores morais parentais.

A identificação com o agressor é o mecanismo de defesa descrito por Anna Freud (Laplanche \& Pontalis, 1977), em que o indivíduo, confrontado com o outro ameaçador, com ele se identifica e adota para si a moral da pessoa do agressor. Segundo Ferenczi (1933/ 1992), que faz uso do conceito de identificação com o agressor nas situações de abuso sexual das crianças, "para proteger-se do perigo que representam os adultos sem controle ela [a criança] deve, em primeiro lugar, saber identificar-se por completo com eles" (p. 105). A mera adesão à vontade parental como forma de o adolescente lidar com a violência do adulto despertada pelo desejo sexual daquele é uma defesa que se coloca no lugar do pensamento e impede a criação de um espaço mental em que a atividade elaborativa e integrativa das experiências emocionais venha a se processar. Em vez de "pensar os pensamentos" (Bion, 1991, p. 118), o psiquismo descarrega as quantidades de excitação pelo caminho da atuação ${ }^{2}$. Alguns de seus efeitos em sala de aula são conhecidos de todos: resolução de conflitos por meio de agressões mútuas, incontinência verbal e motora, e por aí vai.
A identificação com o agressor, ou a adoção para si da vontade do outro também põe em relevo um modo de satisfação pulsional de fundo masoquista. Por que, em vez de identificar-se com aquele que produz dor, dele não fugir? É o que F2 indaga à amiga ao ver marcas em seu corpo. Afinal, quem apanha tem tudo para ser "roqueira, revoltada". Todavia, não é isso que ocorre e prontamente o ser surrado é convertido em ser amado. Se definirmos o amar como a relação do ego com suas fontes de prazer (Freud, 1915/1974), a conversão do ser surrado em ser amado dá indícios do gozo a ser derivado das situações que manifestamente produzem dor. Lembremos das considerações de Freud (1915/1974), a respeito da satisfação pulsional que o sujeito alcança no masoquismo ${ }^{3}$ :

A dor é muito apropriada para proporcionar uma finalidade masoquista passiva, pois temos todos os motivos para acreditar que as sensações de dor, assim como outras sensações desagradáveis, beiram a excitação sexual e produzem uma condição agradável, em nome da qual o sujeito, inclusive, experimentará de boa vontade o desprazer da dor. (p. 149)

$\mathrm{O}$ adolescente aparece, nesse painel, como se pisasse na areia movediça das vicissitudes de suas paixões. Sobre esse solo são cultivadas as relações com as figuras de autoridade socialmente constituídas, como é o caso do professor. As relações banhadas por intensas cargas afetivas ambivalentes põem em risco as diferenças de lugares subjetivos e socialmente construídos entre adultos, crianças e adolescentes e tornam bastante desconfortável o posto, a partir do qual, conforme pontua Kehl (2002), a dose necessária de autoridade justa venha a se exercer.

Encontramos em nossas escolas professores que arriscam sua posição ao estabelecerem relações muito próximas com seus alunos e as quais, não raro, se transformam em relações amorosas de natureza sensual. Em referência a essa questão os adolescentes mencionam que é comum nas escolas haver professores que "ficam" com as alunas e aludem a estes como "safadinhos" e "safadinhas". Na opinião dos jovens a dificuldade dessa situação está no fato de ser impossível distinguir a pessoa do professor dentro e fora da sala de aula. Logo, uma vez que "ficou" com a aluna, desautorizado por seus alunos, ele não é mais respeitado como antes. Não obstante, algumas adolescentes do grupo afirmam que "ficariam" com um professor fora da sala de aula "desde que ele fosse bonitinho $e$ valesse a pena". 
Quando um adolescente "fica" com outro, são dois iguais que se relacionam. Quando ele "fica" com um adulto, entram em jogo as questões da idade e do ganho de status, para ambos os lados. $\mathrm{O}$ adulto, por uma questão de autoafirmação de virilidade, e o adolescente, pelo prazer de se sentir igualado ao adulto. No caso de $o$ adulto ser um professor, essa condição atende a dois desejos do adolescente, visto que, além de igualálo imaginariamente ao adulto, desfaz a relação de autoridade contra a qual, de modo geral, os adolescentes exercem pressão, com o objetivo de constituir sua identidade de adulto.

É fácil deduzir o fascínio que um professor exerce sobre o aluno. Calligaris (2004), ao discutir o que leva um terapeuta a se envolver com uma paciente, fala a respeito de um deslumbramento daquele pela descoberta de sua posição de poder: “"Transar porque pode' não significa só transar porque é fácil, porque o outro é acessível. Significa transar pelo prazer de poder" (p. 47).

Ao atuar responsivamente, isto é, ao se comportar de forma congruente com a fantasia sexual adolescente, o professor eventualmente angaria conquistas; contudo, com esse gesto perde a autoridade que o lugar que ocupa lhe confere. As consequências desse encontro resultam em uma confusão de papéis dentro da sala de aula. Uma vez que "ficou" com a adolescente, o adulto passa a se situar em um lugar que é o mesmo daquele, por conseguinte deixa de sustentar a diferença de posições necessárias ao estabelecimento de vínculos pedagógicos. Essa situação acarreta na sala de aula a perda do respeito dos alunos pelo professor. $\mathrm{O}$ conflito está posto, pois enquanto o adolescente quer levar para a sala de aula a relação de igualdade que houve fora dela, o professor insiste em separar os dois espaços e fracassa nessa missão, visto que seus limites foram esboroados. Do ponto de vista da dinâmica psíquica intersubjetiva, o envolvimento sexual do professor coloca-o perigosamente próximo dos sentimentos hostis concomitantes às transferências eróticas de suas alunas. Hostilidade que as jovens de nosso grupo identificam com falta de respeito e menosprezo à sua postura em sala de aula.

Quando o professor vai a festas "pegar" alunas, ele contribui para retirar da representação professor os significados a ela associados e socialmente construídos, como o respeito e a autoridade. Tais significados, segundo Minerbo (2009), fornecem o lastro necessário para constituir a subjetividade e afetar nossa sensibilidade. A observância aos protocolos ou às formalidades inerentes ao cargo de professor (a "liturgia do cargo" de qualquer profissão) nutre o estofo semântico da palavra professor e dele resulta. E os adolescentes, ainda que irrefletidamente, percebem isso.

\section{Adolescentes, o grupo e a face inconveniente do elogio}

O grupo é um recurso social que os adolescentes usam em seu processo de diferenciação e busca de reconhecimento. Em um movimento gregário típico do adolescente, o mimetismo é um elemento no processo de construção da identidade: "quando você está no meio de pessoas que se vestem e falam de um jeito, você acaba copiando. Não que você queira copiar, é o convivio" (F1). Fazer parte de um grupo, entretanto, requer sacrifícios e conquistas, além de um domínio do universo de regras implícitas que o jovem deve absorver e seguir.

Se, para quem olha de fora, parece haver uma homogeneidade entre os jovens do grupo, do ponto de vista de seus integrantes alguma diferenciação é importante. É preciso haver diferenças individuais, que são aceitas desde que se enquadrem em um desvio padrão aceitável. Dentro do grupo o diferente não agrada muito, porque ameaça romper um vínculo de identificação que é o seu elemento estruturante. Por outro lado, se o integrante for muito "igual", sem nenhuma marca que lhe seja própria, é tomado como alguém sem personalidade, o que, para os adolescentes, não é bem visto.

A "tiração" é um dos recursos que o grupo utiliza para dirigir comportamentos. Se nem sempre é possível obrigar alguém a fazer algo contra sua vontade, ainda é viável fazê-lo desistir da realização de um desejo discordante por meio da "pagação". Todavia, M1 se mostra contra a atitude de fazer tudo o que o grupo quer. Quando os companheiros usam drogas, por exemplo, ele se afasta do grupo e é, então, acusado de se excluir: "você não é obrigado a usar droga porque seus amigos querem. Eu saio de perto. E aí eles perguntam: 'Por que você se exclui?' Eu não me excluo, eu fico em casa, normal, escutando som”. F2 relata uma situação em que precisa omitir das amigas quando "fica" com um menino que não é aprovado pelo grupo, por causa da "pagação". "É muita! Tem gente que perde a noção da coisa, fica uma semana, perigoso ficar até um mês 'pagando' de você!'”. Observa-se que, na fala dos jovens, a pressão exercida pelo grupo tem limites e esbarra em uma resistência que provém de algo que é próprio de cada adolescente e do que, sabe-se lá por quais razões, ele não quer abrir mão. 
Os alunos consideram que, na escola, os grupos se dividem em subgrupos: o das patys, o dos rebeldes e o dos estudiosos. Segundo eles, os preferidos pelos professores são os estudiosos e isso, às vezes, incomoda, bem como incomoda ser elogiado, pois o elogio produz diferenças no grupo e, para os adolescentes, ele deve ser homogêneo. Os jovens mostram os dois ângulos da questão: se, por um lado, o jovem se sente excluído pelo elogio que o professor faz ao colega, por outro lado o elogiado também se sente excluído pelo elogio recebido. Segundo M1, "porque o aluno é inteligente o professor começa a elogiar demais $e$ você se sente... excluído, né? O professor fica elogiando demais o outro, aí você vai e não aprende, você até fica com raiva da matéria". Para F2 o elogio cai como uma sentença: "eu tenho um professor que falou que eu sou muito inteligente. Fiquei destruída! Eu até fiquei com raiva dele, porque se for pra elogiar o aluno, ele deveria falar direto pro aluno, porque dentro da sala fica chato".

Como entender tal desagrado perante um elogio do professor? A respeito desse movimento no grupo, Freud (1921/2006) nos dá pistas para pensarmos o desejo de tratamento uniforme no grupo ou a preservação da indistinção entre seus membros. Trata-se do desenvolvimento de um sentimento comunal baseado na identificação interpares como formação reativa ao sentimento originário de hostilidade dirigido ao rival no amor dos pais e, posteriormente, dos professores. "A primeira exigência feita por essa formação reativa é de justiça, de tratamento igual para todos" (p. 130).

$\mathrm{Na}$ sala de aula não pode haver favoritismo, de modo que, se o indivíduo não é o preferido, ninguém mais o será. Há uma substituição do ciúme por um sentimento grupal. Para Freud (1921/2006) o espírito de grupo não abandona suas raízes, que são originárias da inveja. Todos devem ocupar uma posição de igualdade e ninguém deve pretender salientar-se, todos devem ser e ter o mesmo. Ou seja, se um membro do grupo abdica de algo prazeroso, agradável, ele o faz na expectativa de que todos os outros membros se comportem de modo semelhante. De igual modo, elogios que partem do professor rompem com o equilíbrio alcançado no grupo, visto que não apenas angariam a raiva dos alunos como também a semeiam entre eles, o que resulta em hostilidade dirigida ao colega elogiado. Desse modo, para garantir a uniformidade do grupo, o aluno sente que convém ocultar suas habilidades como forma de evitar destacar-se; tal atitude seria o padrão de comportamento a ser seguido por todos os demais membros do grupo.
A sala de aula, espaço criado com o objetivo precípuo de fazer circular e transmitir o conhecimento acumulado pelas gerações anteriores, é também um espaço onde se dão intensas trocas afetivas. O professor, nesse contexto, é o suporte para a transferência de investimentos afetivos muito antigos e nele atualizados e sobre o qual não tem controle. Embora lhe seja impossível exercer controle sobre o lugar que ocupa na vida psíquica de seus alunos, o professor não deixa de responder aos efeitos nele provocados pelas fantasias daqueles. $\mathrm{O}$ afeto que anima o pensamento tanto favorece como dificulta o processo de aprendizagem: "se você é amiga do professor você aprende melhor" (F1). Por outro lado, "se você não se dá bem com o professor, você não consegue entender a matéria. Você fica olhando a cara dele e imaginando que ele 'se acha'. Ele se acha o dono da escola" (F2). Constata-se certa contaminação da matéria de estudo pela personalidade do professor, que em um extremo de dois polos afetivos se configura como carismática e no outro como repulsiva. A disciplina por ele ministrada acaba sendo investida de suas características pessoais, na lógica do aluno.

$\mathrm{Na}$ avaliação dos alunos, bom professor é aquele que sabe ensinar, ou seja, que é capaz de orientar-se, na sala de aula, pela percepção das dificuldades de compreensão de seus alunos sobre determinado assunto, que explica um assunto de diferentes maneiras, repete as explicações quantas vezes forem necessárias e dá atenção individualizada, se for preciso: "quando eu falo: 'Professora, não entendi, me explica de novo?' Ela vai e me ensina do jeito que eu gosto, do jeito que eu quero, do jeito que eu aprendo" (F4).

Por outro lado, quando o aluno não gosta do professor, seu comportamento é inflexível e às vezes agressivo. F2 reconhece na birra uma estratégia para afrontar o professor: "Eu não gostava dela, e aí eu chegava na sala sem a lição e falava assim: 'Eu não fiz, e daí? Vai fazer o quê?' Professor não manda em mim".

O comportamento obstinado dessa aluna dá a ver o desejo de provocar e chamar a professora para o confronto. Para quê? Para que a professora a submeta, como um dia os pais o fizeram? Ou por que os adolescentes percebem que na escola é possível afirmar-se como um ser desejante, ainda que isso envolva algum grau de agressividade em relação ao objeto/professora? Embora subjugados à vontade parental, como vimos acima, nossos adolescentes encontram na escola as oportunidades para exercitarem a autonomia (" $O$ professor não manda em mim") e a afirmação de um 
desejo próprio ("ela me ensina do jeito que eu gosto, do jeito que eu quero").

É significativo que a transferência belicosa se dê com professores "que não explicam" e "que se acham os donos da escola". Ora, "professores que não explicam" são professores que não aclaram a matéria e, por conseguinte, deixam os alunos sem ter a menor ideia de como realizar as tarefas exigidas. Essa situação de desamparo produz angústia, da qual é preciso se livrar (por meio de comportamentos indisciplinados, por exemplo). Professor que "se acha o dono da escola" não seria a metáfora do professor que se julga com poder de comandar o outro segundo seu arbítrio e vontade pessoal e desse modo despreza as necessidades e os desejos de seus alunos? Em ambos os casos os adolescentes estão diante de objetos que não os reconhecem como sujeitos de desejo e vontade. São objetos vividos como frustrantes.

Não parece ser em casa, e sim na escola, que os adolescentes exercitam a necessária rebeldia para seu crescimento emocional. São os professores que explicam "do jeito que eu gosto, do jeito que eu quero" os que aceitam se submeter de forma benigna ao controle de seus alunos e por isso são queridos. Fazem os adolescentes situarem-se em uma posição ativa ao sentirem que têm algum poder e controle sobre os objetos de que dependem. Poder e controle, ambos derivados não da força despótica do adolescente (a essa força o adolescente precisa encontrar oposição para amadurecer), e sim da acolhida pelo adulto do desejo adolescente de se singularizar.

\section{CONSIDERAÇÕES FINAIS}

De todo o material resultante do grupo de discussão, fica-nos evidente que os jovens, apesar de sua pouca idade, têm discernimento. $\mathrm{O}$ adolescente, esse que está mais para adulto, como diz F2, é um ser em expansão, seus radares estão ligados na vida e ele sabe ler sinais como ninguém.

Tal como o olhar dos pais o olhar dos professores também importa. E prefere-se um professor que cumpra seu papel de educador a um professor colega. Os adolescentes sabem que bom professor é aquele que explica, que se interessa em ensinar e em saber se o aluno realmente aprendeu.

Há uma vantagem no estreitamento da relação entre professor e aluno, pois isso permite que aquele tenha um olhar mais atento para este. Ao invés de generalizar, o professor consegue reconhecer a singularidade de cada um e tirar proveito desse conheci- mento ao incentivar o estudante naquilo que lhe desperta maior interesse, adequando seus métodos de ensino e modos de avaliação ao processo individual de aprendizado.

É perceptível a ligação entre aspectos afetivos e cognitivos na aprendizagem, um servindo de sustentação para o outro. Há um modo de ensinar ao qual o aluno se refere como "o modo que eu gosto". De todas as variações possíveis que surgem daí, um elemento se mantém: o aluno gosta de ser visto, não como mais um, e sim como um singular entre muitos. No entanto, esse olhar atento não se confunde com uma preferência expressa, pelos professores, em relação aos chamados "bons alunos". Quando um professor elogia um aluno, por mais genuíno que isso possa ser, o elogio acaba repercutindo mal para o adolescente, porque o diferencia de todos os outros alunos, que se sentem comparados (e diminuídos) em relação a ele. Sentem-se afrontados e acabam por direcionar sua raiva contra aquele que foi elogiado, o que para este implica sua exclusão de todos os grupos. $\mathrm{O}$ "bom aluno" passa a ser um corpo estranho na sala e fere o código de homogeneidade. Portanto, há um acordo tácito entre os adolescentes de não se destacarem, já que isso resulta em dor e discriminação. Dessa forma, é plausível supor uma ligação entre o medo da exclusão por seus pares e o fato de apresentarem rendimento bem abaixo daquele que exibem em situações particulares e individuais fora do alcance da pressão do grupo.

Concluímos que a aprendizagem depende, em parte, da relação estabelecida entre professor e aluno. Se esta relação tem caráter amistoso, o aluno se vê estimulado a aprender. Cria-se entre eles um espaço de liberdade, que não se confunde, aqui, com a perda de seus papéis de aprendiz e educador. Sempre que o laço professor-aluno ganha conotações sexuais e o professor sai de seu lugar de educador, ele perde a autoridade e mesmo que queira recuperá-la, não encontrará respaldo nos alunos. Cria-se uma situação irreversível, porque se o professor consegue sustentar a cisão entre o que ele é fora e o que ele é dentro da sala de aula, para o aluno essa cisão não existe. $O$ respeito vem junto com o afeto. É querido o professor que ocupa seu lugar, que se faz respeitar porque está ali para facilitar o aprendizado, ser um apoio ao aluno rumo ao conhecimento. Os adolescentes percebem quando o professor não tem no ensino e na aprendizagem dos alunos seu principal foco.

As relações que se estabelecem no rico ambiente escolar repercutem por toda a vida do adolescente. 
Focalizar essas relações com atenção e cuidado é tarefa não apenas desejável, ela é imprescindível. A escola só é campo de aprendizagem porque se coloca sobre um pano de fundo de relações afetivas. Mais do que isso, as relações entram na trama cognitiva e podemos dizer que é justamente nesse complexo campo intersubjetivo que se tecem as aprendizagens.

\section{REFERÊNCIAS}

Ariès, P. (2006). História social da criança e da família. (D. Flaksman, Trad.). (2 ${ }^{\mathrm{a}}$ ed.). Rio de Janeiro: LTC.

Bion, W. R. (1991). O aprender com a experiência. (P. D. Correa, Trad.). Rio de Janeiro: Imago.

Blum, V. L. (2008). Sala de aula e teceduras subjetivas. Educação e Pesquisa, 34(3), 545-556.

Calligaris, C. (2000). A adolescência. São Paulo: Publifolha.

Calligaris, C. (2004). Cartas a um jovem terapeuta. ( $8^{\mathrm{a}}$ ed.). Rio de Janeiro: Elsevier.

Costa, G. P. et al. (2010). A clínica psicanalítica das psicopatologias contemporâneas. Porto Alegre: Artmed.

Ferenczi, S. (1992). Confusão de línguas entre os adultos e a criança: a linguagem da ternura e da paixão. In S. Ferenczi, Psicanálise IV: Obras Completas (pp. 97-108). (A. Cabral, Trad.). São Paulo: Martins Fontes. (Original publicado em 1933)

Figueiredo, L. C. (2009). As diversas faces do cuidar: Novos ensaios de psicanálise contemporânea. São Paulo: Escuta.

Forbes, J. (2005). Mundo mutante, século XXI: As identidades em crise. In J. Forbes, M. Jr. Reale, \& T. S. Jr. Ferraz (Eds.), A in- venção do futuro: um debate sobre a pós-modernidade e a hipermodernidade. Barueri: Manole.

Freud, S. (1974). Os instintos e suas vicissitudes. In S. Freud, Edição Standard Brasileira, Vol. 14 (pp. 137-162) (J. Salomão, Trad.). Rio de Janeiro: Imago. (Original publicado em 1915)

Freud, S. (2006). Psicologia de grupo e análise do ego. In S. Freud, Edição Standard Brasileira, Vol. 18 (pp. 79-154). (J. Salomão, Trad.). Rio de Janeiro: Imago. (Original publicado em 1921)

Gatti, B. A. (2005). Grupo focal na pesquisa em Ciências Sociais e Humanas. Brasília: Líber Livro.

Kehl, M. R. (2002). Quem tem moral com os adolescentes? Duas hipóteses sobre a crise na educação no século XXI. In 4. Colóquio do LEPSI IP/FE-USP. Retirado em 23 de abril de 2009, da base de dados SciELO.

Knobel, M. (1992). A síndrome da adolescência normal. In A. Aberastury, \& M. Knobel. A adolescência normal. (10 ed.). Porto Alegre: Artes Médicas.

Laplanche, J. \& Pontalis, J. B. (1977). Vocabulário da Psicanálise. Lisboa: Moraes editores.

Minerbo, M. (2009). Neurose e não-neurose. São Paulo: Casa do Psicólogo.

Outeiral, J. O. (1994). Adolescer: estudos sobre adolescência. Porto Alegre: Artes Médicas.

Notas:

1 Há no texto duas terminologias; procuramos seguir a nova nomenclatura no que se refere às fases e ciclos do Ensino Fundamental. No entanto, os próprios estudantes ainda não a adotaram na linguagem cotidiana.

2 Segundo Costa et al. (2010, p. 133): “os psicossomatistas franceses concebem o funcionamento psíquico em termos econômicos, distinguindo três formas de tramitação das tensões: a que percorre a via orgânica, a que se faz através da ação e a que segue o caminho do pensamento, com o qual se relaciona o processo de mentalização".

3 Ao trazermos o tema psicanalítico do masoquismo à tona, é de se indagar quão útil seria a hipótese de um destino pulsional masoquista para pensar a faceta inconsciente do complexo fenômeno da violência e sua perpetuação. 